\title{
Evidence base for patient and public involvement in clinical trials (EPIC)
}

\author{
Carrol Gamble*, Louise Dudley, Jennifer Newman \\ From 2nd Clinical Trials Methodology Conference: Methodology Matters \\ Edinburgh, UK. 18-19 November 2013
}

\section{Background}

Patient and public involvement (PPI), inclusion of members of the public as active partners in the research process, can be a requirement of research funding. Limited evidence has suggested that clinical trials may be particularly likely to benefit from PPI. There is a lack of critical assessment of PPI and suggestions in the literature of selective reporting of its benefits. This study aims to increase the knowledge of PPI in clinical trials by systematically investigating how it is approached within a cohort of public funded randomised trials in the UK.

\section{Methods}

Documentation from the application process for all randomised trials funded by the National Institute for Health Research Health Technology Assessment (NIHR HTA) programme between 2006 and 2010 were obtained. Data relating to PPI activity and how these plans were assessed within the peer review process were extracted.

\section{Results}

Documentation to allow details of planned PPI activity to be extracted were available in 107 RCTs. PPI representation was not described in 15\% with representation on TSCs, DMCs, and TMGs described in 53\%, $8 \%$, and $12 \%$ of applications respectively. A consultancy approach was described in $26 \%$.

Of the 515 reviewers comments across the trials only 211(41\%) commented on PPI plans. The majority repeated the PPI plans from the application rather than commenting on their suitability.

University of Liverpool, Liverpool, UK

C 2013 Gamble et al; licensee BioMed Central Ltd. This is an Open Access article distributed under the terms of the Creative Commons Attribution License (http://creativecommons.org/licenses/by/2.0), which permits unrestricted use, distribution, and reproduction in any medium, provided the original work is properly cited.

\section{Conclusions}

Research applicants frequently describe PPI but reviewers seem unable to comment on suitability of the approach. Evidence of impact is needed to inform future approaches for applicants and peer reviewers.

Published: 29 November 2013

Cite this article as: Gamble et al:: Evidence base for patient and public involvement in clinical trials (EPIC). Trials 2013 14(Suppl 1):O34.
doi:10.1186/1745-6215-14-S1-034
Submit your next manuscript to BioMed Central and take full advantage of:

- Convenient online submission

- Thorough peer review

- No space constraints or color figure charges

- Immediate publication on acceptance

- Inclusion in PubMed, CAS, Scopus and Google Scholar

- Research which is freely available for redistribution 